\title{
Determinants of emergency contraception non-use among women in unplanned or ambivalent pregnancies"
}

\author{
DETERMINANTES DO NÃO USO DA ANTICONCEPÇÃO DE EMERGÊNCIA ENTRE \\ MULHERES COM GRAVIDEZ NÃO PLANEJADA OU AMBIVALENTE
}

\section{DETERMINANTES DEL NO USO DE LAANTICONCEPCIÓN DE EMERGENCIA ENTRE MUJERES CON EMBARAZO NO PLANEADO U AMBIVALENTE}

\author{
Osmara Alves dos Santos ${ }^{1}$, Ana Luiza Vilela Borges ${ }^{2}$, Christiane Borges do Nascimento \\ Chofakian $^{3}$, Kátia Cibelle Machado Pirotta ${ }^{4}$
}

\begin{abstract}
Objective: To analyze the determinants of emergency contraception non-use among women in unplanned and ambivalent pregnancies. Method: Cross-sectional study with a probabilistic sample of 366 pregnant women from 12 primary health care units in the city of São Paulo, Brazil. A multinomial logistic regression was performed, comparing three groups: women who used emergency contraception to prevent ongoing pregnancies (reference); women who made no use of emergency contraception, but used other contraceptive methods; and women who made no use of any contraceptive methods at all. Results: Cohabitation with a partner was the common determinant of emergency contraception non-use. No pregnancy risk awareness, ambivalent pregnancies and no previous use of emergency contraception also contributed to emergency contraception non-use. Conclusion: Apart from what is pointed out in the literature, knowledge of emergency contraception and the fertile period were not associated to its use.
\end{abstract}

\section{DESCRIPTORS}

Pregnancy unplanned Contraceptives postcoital

Family planning

Reproductive health

Primary health care.

\section{RESUMO}

Objetivo: Analisar os determinantes do não uso da anticoncepção de emergência entre mulheres com gravidez não planejada ou ambivalente. Método: Estudo transversal com amostra probabilística de 366 gestantes de 12 Unidades Básicas de Saúde da cidade de São Paulo. Por meio de regressão logística multinomial, compararam-se três grupos de mulheres: as que usaram anticoncepção de emergência para prevenir a gravidez em curso (referência); as que usaram algum método contraceptivo, mas não anticoncepção de emergência; e as que não usaram nenhum método. Resultados: Os achados mostraram que morar com o parceiro foi o determinante comum do não uso da anticoncepção de emergência. Não ter consciência do risco de engravidar, estar em uma gravidez ambivalente e nunca ter usado anticoncepção de emergência também foram associados ao seu não uso para prevenir a gravidez em curso. Conclusão: Diferentemente do que relata a literatura, o conhecimento sobre anticoncepção de emergência e sobre o período fértil não mostrou qualquer associação ao não uso.

\section{DESCRITORES \\ Gravidez não planejada \\ Anticoncepcionais pós-coito \\ Planejamento familiar \\ Saúde reprodutiva \\ Atenção Primária à Saúde}

\begin{abstract}
RESUMEN
\author{
DESCRIPTORES \\ Embarazo no planeado \\ Anticonceptivos poscoito \\ Planificación familiar \\ Salud reproductiva \\ Atención Primaria de Salud
}

Objetivo: Analizar los determinantes del no uso de la anticoncepción de emergencia entre las mujeres con embarazo no planeado o ambivalente. Método: Estudio transversal en una muestra probabilística de 366 mujeres embarazadas de 12 Unidades Básicas de Salud de São Paulo. Mediante regresión logística multinomial, se comparó tres grupos de mujeres: aquellas que usaron la anticoncepción de emergencia para prevenir el embarazo en curso (referencia), aquellas que usaron algún método anticonceptivo, pero no la anticoncepción de emergência; y aquellas que no usaron ningún método. Resultados: Los hallazgos mostraron que vivir com la pareja fue el determinante común del no uso de la anticoncepción de emergencia. No tener conciencia del riesgo de embarazo, estar en un embarazo ambivalente y nunca tener utilizado la anticoncepción de emergencia también fueron associados con su no uso para prevenir el embarazo en curso. Conclusión: Contrariamente a lo que reporta la literatura, el conocimiento de la anticoncepción de emergencia y el período fértil no mostró asociación con el no uso.

\footnotetext{
* Extracted from the dissertation "Razões do não uso da anticoncepção de emergência quando indicada", Nursing School, University of São Paulo, 2014. ${ }^{1}$ Doctoral student, Nursing School of the University of São Paulo, São Paulo, São Paulo, Brazil. ${ }^{2}$ Ph.D. Professor, Collective Health Nursing Department, Nursing School of the University of São Paulo, São Paulo, São Paulo, Brazil. ${ }^{3}$ Doctoral student, Nursing School of the University of São Paulo, São Paulo, São Paulo, Brazil. ${ }^{4}$ Scientific IV Researcher, Health Institute, Health Department of the State of São Paulo, São Paulo, São Paulo, Brazil. 


\section{INTRODUCTION}

Even though the percentage use of contraceptive methods in Brazil reaches a high value of $80 \%$ in all women, unwanted pregnancies are still persistent and represented $44 \%$ of all births in the five years before the Demographic and Health Survey (DHS) in 2006 ${ }^{(1)}$. Occurrence of unwanted pregnancies is considered as a flaw indicator in reproductive health care. This flaw can occur due to multiple situations, such as unprotected sex, incorrect or non-use of contraceptive methods, unsuccessful negotiations with the partner for the use of contraception, and poor access to contraceptive counseling and methods ${ }^{(2,3)}$.

Reproductive health care is defined as a combination of methods, techniques and services that enable people to enjoy a safe and fulfilling sexual life, acknowledging women's ability to decide whether to have children, the best time for becoming pregnant, and the desired frequency of pregnancy. Services guided by such objectives are recommended to be included in the scope of primary health care. This concept was consolidated in two important international conferences held in 1994 in Cairo and in Beijing the following year. People's autonomy in dealing with reproductive matters and gender relationships is also acknowledged, with a view to not restraining care, but only providing health care and prevention ${ }^{(4)}$.

In Brazil, the creation of the National Commission of Population and Development in 1995, and the Family Planning Law (Law No 9.263, from January 12, 1996), represent important milestones in the construction of a reproductive planning policy consonant with the principles in the platforms from Cairo and Beijing. Access to a range of highly efficient contraceptive methods is one of the basic elements of this policy. Emergency contraception $(E C)$ is one of these methods. Health services must ensure that it is offered to women by means of the established indications for their use, which is indicated in cases when regular contraceptive methods were not used, when there was a failure in contraceptive methods, and in cases of sexual violence ${ }^{(5)}$. Despite its efficiency, EC is still underused throughout the world, especially in developing countries, except for some countries in Western Europe and China ${ }^{(6)}$. This means that there are many situations experienced by couples and women in which the use of EC would be indicated, but, for many reasons, it is not used.

There is little knowledge about why women of reproductive age for whom EC is indicated make no use of it. Studies demonstrate that low awareness of pregnancy risk is the main contributor to $\mathrm{EC}$ non-use $\mathrm{e}^{(7,8)}$. Other authors also point out that low knowledge of EC, extreme age brackets (under 20 and older than 40), low educational level, having had children and having experienced a previous abortion are all associated with EC non-use ${ }^{(7,9)}$.
In Brazil, no studies were found regarding the determinants of EC non-use. Considering the persistence of unwanted pregnancies ${ }^{(1)}$ and abortions with severe consequences to reproductive health or maternal de$a h^{(10)}$, it is supposed that many Brazilian women could benefit from the use of EC, but they never adopt the method. Our hypothesis was that lack of pregnancy risk awareness contributes to EC non-use, as in Brazil, the literature about the use of EC, although focused on specific groups such as adolescents and college students, shows no problems in the access to the method, mostly because it is largely acquired in commercial pharmacies $^{(11-12)}$. However, it is also important to understand the effect of other aspects, such as the level of knowledge about EC, educational level, and cohabitation, on EC non-use. Therefore, our objective was to analyze the determinants of EC non-use.

\section{METHOD}

A quantitative cross-sectional study was performed on a probabilistic sample of pregnant women from 12 primary health care units (PHU) from an administrative supervision of the City of São Paulo $(n=366)$. Women were selected based on stratified sampling considering the proportion of pregnant women enrolled in each PHU in 2012.

Since it is not possible to evaluate the need for early use of EC, unplanned and ambivalent pregnancies were considered situations when EC use would have been indicated. Therefore, women who were classified as being in an unplanned or ambivalent pregnancy were selected, according to the London Measure of Unplanned Pregnancy (LMUP) instrument ${ }^{(13,14)}$. This instrument was used because it does not locate women in a dichotomic position of planned or unplanned pregnancy, but considers women as having ambivalent attitudes and intentions ${ }^{(15)}$.

Data collection occurred from April to July of 2013 and was performed by interviewing all pregnant women who sought services at the PHU for all types of care, such as prenatal appointments, immunizations and educational groups. A structured instrument was used with questions about sociodemographic profile, reproductive history, contraceptive history, knowledge about EC, prior use of EC and the use of EC to prevent the current pregnancy. Each interview lasted 15 to 20 minutes.

The dependent variable was the non-use of EC to prevent current pregnancy. The reference group was composed of women who used EC to prevent current pregnancy. Two groups were compared to the reference group: one group of women who used contraceptive methods, but not EC, in the month they became pregnant; and one group of women who used no contraceptive methods in that same period. 
The independent variables were: pregnancy risk awareness, checked by the question Were you aware you could become pregnant when you had sexual relation? ${ }^{(8)}$; educational level (in years); the level of knowledge about EC, by using eight questions adapted from Nascimento (2012)(16); economic classification, where the 2010 Brazil Economic Classification criteria was used $(A, B, C, D$ and $E$, where $A$ is the wealthiest group and $\mathrm{E}$ the poorest); cohabitation (whether living with a partner); previous use of EC (Yes or No); planning of the current pregnancy (ambivalent and unplanned); having children (Yes or No); skin color (white or other); and knowledge about the fertile period, checked by the question from the 2006 DHS, At which time in your menstrual period, in other words, between the beginning of one period and the beginning of the next, do women have a higher chance of becoming pregnant?: during the menstrual period; as soon as the menstrual period ends; in the middle of the period; a little before the beginning of the period; at any time; other; don't know. Women who answered in the middle of the period were classified as knows and women chose the other alternatives were classified as doesn't know and categorized as Yes or No.

Instrument input was performed directly into FormSUS and statistical analyses were done in Stata 12.0. The analysis of determinants of EC non-use was performed with multinomial logistic regression. Initially, a bivariate analysis was performed to compare the three groups by proportions, means, medians and standard deviations. The difference between proportions was tested by Chi-square test or by the Fisher Exact test and the medians by variance analysis.

The choice of variables to compose the multinomial logistic regression model obeyed the following criteria: 1 ) be reported in the study hypothesis; 2 ) value $p<0.20$ in the bivariate analysis; 3 ) educational level, due to its importance in contraceptive methods use in general ${ }^{(1)}$; and 4) knowledge about the fertile period, since it contributes to making women aware of pregnancy risk. The final model was chosen by using the Akaike Information Criterion (AIC).

The present study was approved by the Research Ethics Committee authorized by the Research Ethics National Council (process 350.320/2011) and all the ethical principles on research on human beings were followed.

\section{RESULTS}

Among all 366 women interviewed, 96 had their current pregnancy classified as unplanned and 270 as ambivalent. Women were, on average, 25 years old $(S D=6.5)$. Most women were brown and belonged to the $\mathrm{C}$ economic class. They were also Catholic, living with a partner, and had, on average, 9.5 years of education $(S D=2.4)$.

According to Table 1, the following variables were independent factors in the multinomial analysis $(p<0.20)$ : awareness of pregnancy risk, living with a partner, color, having children, previous use of EC, planning the current pregnancy, and level of knowledge about EC. Variables regarding knowledge of the fertile period and educational level presented $p>0.20$; however, they were kept in the multinomial analysis due to criteria established to construct the model.

Multinomial logistic regression final model is presented in Table 2. Regarding the women who were using contraceptive method in the month they became pregnant, but made no use of EC to prevent the current pregnancy, those who had no awareness of pregnancy risk and lived with partner stand out because they presented higher odds of not using EC, compared to women who used EC to prevent current pregnancy (OR=3.44 [CI95\%:1.48-8.03]; $\mathrm{OR}=3.23$ [Cl95\%:1.43-7.28], respectively).

For women who were not using contraceptive methods in the month they became pregnant and did not use EC to prevent current pregnancy, it was demonstrated that those living with partner (OR=3.19 Cl95\%:1.40-7.27), with ambivalent pregnancies (OR=3.40 Cl95\%:1.56-8.54) and who had never used EC before $(\mathrm{OR}=3.52$ [Cl95\%=1.388.97]) presented higher odds of not using $E C$, compared to women who used EC to prevent current pregnancy.

Living with a partner presented an effect on EC nonuse for both groups. However, knowing the fertile period and educational level showed no effect on EC non-use to prevent current pregnancy. Color and having children, although significant in the bivariate analysis, lost significance when analyzed together with other variables in the multinomial model.

Table 1 - Number, proportion, mean and standard deviation of women according to the use of contraceptive methods in the month they became pregnant - São Paulo, 2013

\begin{tabular}{|c|c|c|c|c|c|c|c|c|c|}
\hline \multirow{3}{*}{ Variables } & \multicolumn{9}{|c|}{ Use of Contraceptive Methods } \\
\hline & \multicolumn{2}{|c|}{$\begin{array}{c}\text { Women who used EC } \\
\text { to prevent current } \\
\text { pregnancy }\end{array}$} & \multicolumn{2}{|c|}{$\begin{array}{c}\text { Women who used a } \\
\text { contraceptive method } \\
\text { but not EC* }\end{array}$} & \multicolumn{2}{|c|}{$\begin{array}{l}\text { Women who used } \\
\text { neither contraceptive } \\
\text { method nor EC* }\end{array}$} & \multicolumn{2}{|c|}{ Total } & \multirow[t]{2}{*}{$\mathbf{p}^{* *}$} \\
\hline & $\mathbf{N}$ & $\%$ & $\mathbf{N}$ & $\%$ & $\mathbf{N}$ & $\%$ & $\mathbf{N}$ & $\%$ & \\
\hline \multicolumn{10}{|c|}{ Pregnancy risk awareness } \\
\hline No & 9 & 25.0 & 86 & 53.1 & 32 & 19.1 & 127 & 34.7 & $<0.001$ \\
\hline Yes & 27 & 75.0 & 76 & 46.9 & 136 & 81.0 & 239 & 65.3 & \\
\hline \multicolumn{10}{|c|}{$\begin{array}{l}\text { Knowledge about the fertile } \\
\text { period }\end{array}$} \\
\hline No & 29 & 80.6 & 136 & 84.0 & 145 & 86.3 & 310 & 84.7 & 0.643 \\
\hline Yes & 7 & 19.4 & 26 & 16.1 & 23 & 13.7 & 56 & 15.3 & \\
\hline
\end{tabular}

Determinants of emergency contraception non-use among women in unplanned or ambivalent pregnancies Santos CA, Borges ALV, Chofakian CBN, Pirotta KCM 


\begin{tabular}{|c|c|c|c|c|c|c|c|c|c|}
\hline \multirow{3}{*}{ Variables } & \multicolumn{9}{|c|}{ Use of Contraceptive Methods } \\
\hline & \multicolumn{2}{|c|}{$\begin{array}{c}\text { Women who used EC } \\
\text { to prevent current } \\
\text { pregnancy }\end{array}$} & \multicolumn{2}{|c|}{$\begin{array}{c}\text { Women who used a } \\
\text { contraceptive method } \\
\text { but not EC* }\end{array}$} & \multicolumn{2}{|c|}{$\begin{array}{c}\text { Women who used } \\
\text { neither contraceptive } \\
\text { method nor EC* }\end{array}$} & \multicolumn{2}{|c|}{ Total } & \multirow[t]{2}{*}{$\mathbf{p}^{* *}$} \\
\hline & $\mathbf{N}$ & $\%$ & $\mathbf{N}$ & $\%$ & $\mathbf{N}$ & $\%$ & $\mathbf{N}$ & $\%$ & \\
\hline \multicolumn{10}{|l|}{ Living with a partner } \\
\hline No & 17 & 47.2 & 35 & 21.6 & 33 & 19.6 & 85 & 23.2 & $<0.001$ \\
\hline Yes & 19 & 52.8 & 127 & 78.4 & 135 & 80.4 & 281 & 76.8 & \\
\hline \multicolumn{10}{|l|}{ Color } \\
\hline White & 12 & 33.3 & 49 & 30.3 & 36 & 21.4 & 97 & 26.5 & 0.120 \\
\hline Non-white & 24 & 66.7 & 113 & 69.8 & 132 & 78.6 & 269 & 75.5 & \\
\hline \multicolumn{10}{|l|}{ Economic class } \\
\hline $\mathrm{A} / \mathrm{B}$ & 8 & 22.2 & 26 & 16.0 & 34 & 20.2 & 68 & 18.6 & 0.807 \\
\hline $\mathrm{C}$ & 25 & 69.4 & 120 & 74.1 & 112 & 66.7 & 257 & 70.2 & \\
\hline $\mathrm{D} / \mathrm{E}$ & 3 & 8.3 & 15 & 9.3 & 15 & 8.9 & 33 & 9.0 & \\
\hline No answer & - & - & 1 & 0.6 & 7 & 4.2 & 8 & 2.2 & \\
\hline \multicolumn{10}{|l|}{ Religion } \\
\hline Catholic & 12 & 33.3 & 68 & 42.0 & 65 & 38.7 & 145 & 39.6 & 0.286 \\
\hline Protestant & 12 & 33.3 & 62 & 38.3 & 52 & 31.0 & 126 & 34.4 & \\
\hline None & 10 & 27.8 & 22 & 13.6 & 38 & 22.6 & 70 & 19.1 & \\
\hline Others $* * *$ & 2 & 5.6 & 10 & 6.2 & 13 & 7.6 & 25 & 6.8 & \\
\hline \multicolumn{10}{|l|}{ Previous abortion } \\
\hline No & 29 & 80.6 & 126 & 77.8 & 129 & 76.8 & 284 & 77.6 & 0.883 \\
\hline Yes & 7 & 19.4 & 36 & 22.2 & 39 & 23.2 & 82 & 22.4 & \\
\hline \multicolumn{10}{|l|}{ With children } \\
\hline No & 16 & 44.4 & 56 & 34.6 & 87 & 51.8 & 159 & 43.4 & 0.007 \\
\hline Yes & 20 & 55.6 & 106 & 65.4 & 81 & 48.2 & 207 & 56.6 & \\
\hline \multicolumn{10}{|l|}{ Previous use of EC } \\
\hline No & 7 & 19.4 & 69 & 42.6 & 86 & 51.2 & 162 & 44.3 & 0.002 \\
\hline Yes & 29 & 80.6 & 93 & 57.4 & 82 & 48.8 & 204 & 55.7 & \\
\hline \multicolumn{10}{|l|}{ Planning current pregnancy } \\
\hline Ambivalent & 22 & 61.1 & 102 & 63.0 & 146 & 86.9 & 270 & 73.8 & $<0.001$ \\
\hline Unplanned & 14 & 38.9 & 60 & 37.0 & 22 & 13.1 & 96 & 26.2 & \\
\hline \multirow[t]{2}{*}{ Variables } & Mean & & Mean & & Mean & & Total & & $\mathrm{p}^{* * *}$ \\
\hline & SD & & SD & & SD & & & & \\
\hline Age (in years) & $25.2(6.2)$ & & $25.4(6.4)$ & & $24.6(6.8)$ & & $25.0(6.5)$ & & 0.576 \\
\hline Educational level (in years) & $9.7(2.0)$ & & $9.4(2.3)$ & & $9.4(2.6)$ & & $9.5(2.4)$ & & 0.856 \\
\hline Level of knowledge about EC & $4.2(2.1)$ & & $3.6(2.0)$ & & $3.3(2.0)$ & & $3.5(2.0)$ & & 0.056 \\
\hline Total & 36 & & 162 & & 168 & & 366 & & \\
\hline
\end{tabular}

Table 2 - Final model of multinomial logistic regression for the analysis of emergency contraception non-use to prevent current pregnancy - São Paulo, 2013

\begin{tabular}{|c|c|c|c|c|}
\hline \multirow{2}{*}{ Variable } & \multicolumn{2}{|c|}{ Women who used a contraceptive method but not EC* } & \multicolumn{2}{|c|}{ Women who used neither contraceptive methods nor EC" } \\
\hline & OR & CI 95\% & OR & CI 95\% \\
\hline \multicolumn{5}{|c|}{ Pregnancy risk awareness } \\
\hline No & 3.44 & $1.48-8.03 * *$ & 0.78 & $0.32-1.90$ \\
\hline Yes & 1.00 & - & 1.00 & - \\
\hline \multicolumn{5}{|c|}{$\begin{array}{l}\text { Knowledge about the } \\
\text { fertile period }\end{array}$} \\
\hline No & 1.27 & $0.46-3.51$ & 1.23 & $0.44-3.42$ \\
\hline Yes & 1.00 & - & 1.00 & - \\
\hline \multicolumn{5}{|c|}{ Living with a partner } \\
\hline No & 1.00 & - & 1.00 & - \\
\hline Yes & 3.23 & $1.43-7.28 * *$ & 3.19 & $1.40-7.27 * * *$ \\
\hline \multicolumn{5}{|l|}{ With children } \\
\hline No & 0.76 & $0.33-1.77$ & 1.21 & $0.52-2.78$ \\
\hline Yes & 1.00 & - & 1.00 & - \\
\hline
\end{tabular}




\begin{tabular}{|c|c|c|c|c|}
\hline \multirow{2}{*}{ Variable } & \multicolumn{2}{|c|}{ Women who used a contraceptive method but not EC* } & \multicolumn{2}{|c|}{ Women who used neither contraceptive methods nor EC: } \\
\hline & OR & CI 95\% & OR & CI $95 \%$ \\
\hline Educational level (in years) & 0.99 & $0.84-1.17$ & 0.96 & $0.81-1.13$ \\
\hline \multicolumn{5}{|l|}{ Color } \\
\hline White & 0.95 & $0.41-2.16$ & 0.64 & $0.27-1.48$ \\
\hline Non-white & 1.00 & - & 1.00 & - \\
\hline \multicolumn{5}{|l|}{$\begin{array}{l}\text { Planning current } \\
\text { pregnancy }\end{array}$} \\
\hline Ambivalent & 1.10 & $0.46-2.62$ & 3.40 & $1.56-8.54 * * *$ \\
\hline Unplanned & 1.00 & - & 1.00 & - \\
\hline $\begin{array}{l}\text { Level of knowledge about } \\
\text { EC }\end{array}$ & 0.94 & $0.76-1.16$ & 0.90 & $0.72-1.11$ \\
\hline \multicolumn{5}{|l|}{ Previous use of EC } \\
\hline No & 2.6 & $1.00-6.61$ & 3.52 & $1.38-8.97 * * *$ \\
\hline Yes & 1.00 & - & 1.00 & - \\
\hline
\end{tabular}

\section{DISCUSSION}

We observed a diversified sociodemographic profile. Women's characteristics ranged from first pregnancy adolescents to single and married mature women with children. This diversity in affective-loving relationships and reproductive history is relevant, once the number of children and the marital status usually influence contraception use ${ }^{(17)}$.

Determinants of the reason for EC non-use were identified within a specific population of women who were not able to plan their current pregnancy. Pregnancy risk awareness, living with a partner, planning the pregnancy and the previous use of EC were determinant variables for EC non-use.

Living with a partner was the only variable associated with EC non-use both for women who used contraceptive methods and for women who did not use contraceptives in the month they became pregnant. These findings are compared to other studies ${ }^{(7,18,19)}$ in which married women or women who lived with partners were less likely to use contraceptive methods than single women and women who did not live with partners, possibly because the former feel that life circumstances are favorable for pregnancy, even when not expected. It is important to point out that not only cohabiting with a partner, but also reproductive intentions of the partners, can mold contraceptive practices ${ }^{(20-21)}$. Moreover, it is more common for those women who do not live with partners to have casual or unstable relationships, making them more vulnerable to face an unexpected pregnancy. In this case, it would be most likely for them to resort to EC.

Only for women who used contraception, but not EC, in the month they became pregnant, lack of pregnancy risk awareness was determinant for EC non-use. In order to accept the use of EC, women must first be aware of pregnancy risk ${ }^{(22)}$. For women who make no regular use of contraceptive methods, it is natural and expected that they have a certain awareness of the pregnancy risk, except those who, for some reason, are considered infer- tile or are with infertile partners. On the other hand, for women who make regular use of contraceptive methods, it is more difficult to acknowledge the risk of pregnancy, since they are, supposedly, more protected and don't always have control of their menstrual period, as in cases when hormonal contraceptives are used ${ }^{(8,23)}$. This explains why a higher proportion of women had no pregnancy risk awareness. In addition, to understand which failures occurred in the contraceptive method, many of these women may not have had knowledge of the situations in which they could have used EC, since they acknowledged no risk of becoming pregnancy.

Planning the current pregnancy was the only determinant for EC non-use among women who used neither contraceptive methods nor EC in the month they became pregnant. Women who were ambivalent regarding pregnancy planning presented 3.4 times the odds of EC nonuse than women who had unplanned pregnancy. In a study carried out with married women, intentions regarding pregnancy were the only aspects associated with EC us $\mathrm{e}^{(24)}$. In another study performed in Edinburgh, Scotland, women who presented an ambivalent pregnancy also reported less use of EC than women with unplanned pregnancy ${ }^{(25)}$. No information was found on how ambivalent reproductive intentions affect contraceptive practices and how they do it, as this aspect has been little explored in recent studies ${ }^{(26)}$. Studies have demonstrated that couple's plans regarding reproduction are not necessarily clear and can be vague and unspecific ${ }^{(15,27)}$. We can see that, for these women, the possibility of a pregnancy, even when mistimed, is not sufficient to influence the regular use of contraceptive methods, even less so for EC, which is the last resort after an unprotected sexual relation. It seems that personal circumstances strongly influence EC use. So, in fact, living with a partner and ambivalence around planning a pregnancy were strong determinants of EC non-use, confirming that contraception is not a completely rational phenomenon, but subjective and contextual.

Never having used EC was associated with EC non-use among women who made use of contraceptive methods in 
the month they became pregnant. These women presented a 3.52 odds of not employing EC to prevent the ongoing pregnancy than women who had already used it, as described elsewhere ${ }^{(19,28,29)}$. This may be related to the fact that women who successfully experienced using EC may be more motivated to resort to this method again in case they need.

Although considered a strong determinant of EC use $e^{(9,18,28)}$, the level of knowledge about the method showed no effect in its use, similar to findings about knowledge of the fertile period. Actually, few women could correctly identify the fertile period, indicating that it might be not an important component in contraceptive behavior. One study called our attention to the fact that women do not always relate the fertile period to ovulation and that knowledge of the fertile period does not necessarily imply applying that knowledge ${ }^{(30)}$. The same can be said regarding specific knowledge about EC.

Curiously, social aspects such as educational level, economic class and color, and reproductive history, such as having children and experiencing abortion, showed no effect on EC non-use in the present study. Even though contextual/relational aspects have prevailed as associated with EC non-use, we have not disregarded social status as an influencing factor in reproductive intentions and, consequently, contraceptive practices.

It is important to point out that these findings represent neither women who have successfully prevented pregnancies with the use of EC, nor women who were classified as having a planned pregnancy. The findings also do not represent women who attended private or supplementary health services. Future studies may take these aspects under consideration, and also explore in a broader way the role of the partner and ambivalence in pregnancy planning (or the intention of becoming pregnant) in the decision to use EC.

Therefore, in this study, we used a validated instrument to classify pregnancy planning, which enabled reliable findings about the indications for EC use by this group. Finally, this study presents previously unseen information on the determinants of EC non-use in Brazil, contributing to pointing out the ways to enhance its use.

\section{CONCLUSION}

Determinant aspects that contributed to EC non-use to prevent unplanned or ambivalent pregnancies were different, depending on women's previous use or non-use of a contraceptive method in the month they became pregnant. Living with a partner had a significant effect on EC non-use among women as a whole. Determinants about EC non-use for women who used contraceptive methods in the month they became pregnant were unawareness of the pregnancy risk and living with a partner; among women who did not use contraceptive methods, the determinants were living with a partner, an ambivalent pregnancy and previous use of EC.

These results reaffirm the need for health professionals to consider ambivalence regarding the intention to become pregnant and the type of relationship during counseling and contraception. Anyway, acknowledging situations when there is a risk of becoming pregnant, knowing by experience how to obtain and use the method and having clear reproductive intentions may enhance EC use when indicated.

\section{REFERENCES}

1. Brasil. Ministério da Saúde; Centro Brasileiro de Análise e Planejamento. Pesquisa Nacional de Demografia e Saúde da Criança e da Mulher - PNDS 2006: Relatório Final [Internet]. Brasília; 2008 [citado 2014 mar. 19]. Disponível em: http://bvsms. saude.gov.br/bvs/pnds/img/relatorio_final_pnds2006.pdf

2. Brasil. Ministério da Saúde. Aborto e Saúde Pública no Brasil: 20 anos [Internet]. Brasília; 2009 [citado 2014 mar. 19]. Disponível em: http://bvsms.saude.gov.br/bvs/publicacoes/ livro_aborto.pdf

3. Organización Mundial de la Salud. Planificación familiar [Internet]. Ginebra; 2011 [citado 2014 mar. 19]. Disponible en: http:// www.who.int/mediacentre/factsheets/fs351/es/index.html

4. World Health Organization. Emergency contraception [Internet]. Geneva: WHO; 2012 [cited 2014 Mar 19]. Available from: http://www.who.int/mediacentre/factsheets/fs244/en/

5. Fundo de Populações das Nações Unidas. Planejamento familiar no Brasil, 50 anos de história. In: Conclusões do evento comemorativo ao Dia Mundial de População no Brasil; 2008 jul. 11; Brasília, DF [Internet]. Brasília: UNFPA; 2008 [citado 2014 mar. 19]. Disponível em: http://www.unfpa.org.br/Arquivos/relatoriowpd.pdf

6. Cheng L, Che Y, Gülmezoglu AM. Interventions for emergency contraception. Cochrane Database Syst Rev. 2012;(8):CD001324.

7. Meng CX, Gemzell-Danielsson K, Stephansson O, Kang JZ, Chen QF, Cheng LN. Emergency contraceptive use among 5677 women seeking abortion in Shanghai, China. Hum Reprod. 2009;24(7):1612-8.

8. Moreau C, Bouyer J, Goulard H, Bajos N. The remaining barriers to the use of emergency contraception: perception of pregnancy risk by women undergoing induced abortions. Contraception. 2005;71(3):202-7. 
9. Tilahun FD, Assefa T, Belachew T. Predictors of emergency contraceptive use among regular female students at Adama University, Central Ethiopia. Pan Afr Med J [Internet]. 2010 [cited 2014 Mar 19];7:16. Available from: http://www.ncbi. nlm.nih.gov/pmc/articles/PMC3172641/

10. Diniz D, Medeiros M. Aborto no Brasil: uma pesquisa domiciliar com técnica de urna. Ciên Saúde Coletiva. 2010; 15(1):959-66.

11. Borges ALV, Fujimori E, Hoga LAK, Contin MV. Práticas contraceptivas entre jovens universitários: o uso da anticoncepção de emergência. Cad Saúde Pública. 2010;26(4):816-26.

12. Silva FC, Vitalle MSS, Maranhão HS, Canuto MHA, Pires MMS, Fisberg M. Diferenças regionais do conhecimento, opinião e uso de contraceptivo de emergência entre universitários brasileiros de cursos da área de saúde. Cad Saúde Pública. 2010; 26(9):1821-31.

13. Barrett G, Smith SC, Wellings K. Conceptualisation, development, and evaluation of a measure of unplanned pregnancy. J Epidemiol Community Health. 2004;58(5):426-33.

14. Borges ALV, Cavalhieri FB, Hoga LAK, Fujimori E, Barbosa LR. Pregnancy planning: prevalence and associated aspects. Rev Esc Enferm USP [Internet]. 2011 [cited 2014 Mar 19];45(n. spe2):1679-84. Available from: http://www.scielo.br/pdf/ reeusp/v45nspe2/en_07.pdf

15. Barret G, Wellings K. What is a planned pregnancy? Empirical data from a British study. Soc Sci Med. 2002;55(4):54557.

16. Fujimori E, Hoga LAK. Conhecimento sobre anticoncepção de emergência entre adolescentes do Ensino Médio de escolas públicas e privadas. Cad. Saúde Pública 2014; 30(7): 1525-36.

17. Perpétuo IHO. Anticoncepção. In: Brasil. Ministério da Saúde; Centro Brasileiro de Análise e Planejamento. Pesquisa Nacional de Demografia e Saúde da Criança e da Mulher - PNDS 2006: Relatório Final [Internet]. Brasília; 2008 [citado 2014 mar. 19]. p.128-42. Disponível em: http://bvsms. saude.gov.br/bvs/pnds/img/relatorio_final_pnds2006.pdf

18. 1 Kozinszky Z, Sikovanyecz J, Devosa I, Szabó D, Barabás K, Pál $A$, et al. Determinants of emergency contraceptive use after unprotected intercourse: Who seeks emergency contraception and who seeks abortion? Acta Obstet Gynecol Scand. 2012;91(6):959-64.

19. Campo S, Askelson NM, Spies EL, Losch M. Ambivalence, communication and past use: understanding what influences women's intentions to use contraceptives. Psychol Health
Med. 2012;17(3):356-65.

20. Bartz D, Shew M, Ofner S, Fortenberry JD. Pregnancy intentions and contraceptive behaviors among adolescent women: a coital event level analysis. J Adolesc Health. 2007;41(3):271-6.

21. Rocca $\mathrm{CH}$, Krishnan S, Barrett G, Wilson M. Measuring pregnancy planning: an assessment of the London Measure of Unplanned Pregnancy among urban, south Indian women. Demogr Res. 2010;23:293-334.

22. Williamson LM, Buston K, Sweeting H. Young women's rceptions of pregnancy risk and use of emergency contraception: findings from a qualitative study. Contraception. 2009;79(4):310-5.

23. Frohwirth L, Moore AM, Maniaci R. Perceptions of susceptibility to pregnancy among U.S. women obtaining abortions. Soc Sci Med. 2013;99:18-26.

24. Rocca CH, Shankar M, Sreevathsa A, Krishnan S. Acceptability and use of emergency contraception among married women in Bangalore, India. Int J Gynaecol Obstet. 2013;121(1):64-8.

25. Lakha F, Glasier A. Unintended pregnancy and use of emergency contraception among a large cohort of women attending for antenatal care or abortion in Scotland. Lancet. 2006;368(9549):1782-7.

26. Moreau C, Hall K, Trussell J, Barber J. Effect of prospectively measured pregnancy intentions on the consistency of contraceptive use among young women in Michigan. Hum Reprod. 2013;28(3):642-50.

27. Gribaldo A, Judd MD, Kertzer DI. An imperfect contraceptive society: fertility and contraception in Italy. Popul Dev Rev. 2009;35(3):551-84.

28. Rocca CH, Schwarz EB, Stewart FH, Darney PD, Raine TR, Harper CC. Beyond access: acceptability, use and nonuse of emergency contraception among young women. Am J Obstet Gynecol. 2007;196(1):29.e1-6.

29. Adeniji AO, Tijani AM, Owonikoko KM. Knowledge and determinants of emergency contraception use among students in tertiary institution in Osun State, Nigeria. J Basic Clin Reprod Sci. 2013;2(1):46-53.

30. Carvacho IE, Silva JLP, Mello MB. Conhecimento de adolescentes grávidas sobre anatomia e fisiologia da reprodução. Rev Assoc Med Bras. 2008;54(1):29-35 